\title{
LITERARY ANNUALS AND GIFT BOOKS
}

\author{
By Alan E. James
}

Sbortly after the appearance in 1936 of American Literary Annuals \& Gift Books I 825-1 865 by Dr. Ralpb Tbompson, a former instructor of Englisb at Rutgers, Mr. Alan E. Fames, of the class of 1928 and now on the staff of the Library, compared the boldings of literary annuals and gift books in the Rutgers Library with the titles given in Dr. Thompson's extensive bibliograpby. $M r$. Fames found that Rutgers owned, in addition to about a third of the total number of books, some forty-six new titles or variants wbicb were unknown to Dr. Tbompson or to any otber bibliograpber of these curious and often rare publications. The following list will give students of American literature furtber materials for enlarging our knowledge of literary America a century ago.

I

$\mathrm{N}$ the last month of the first quarter of the nineteenth century the pioneer issue of a new type of American publication appeared in the book-stores. Entitled The Atlantic Souvenir, a Cbristmas and New Year's Offering and published by Carey and Lea in Philadelphia, it led a procession which was destined to sweep across the field of belles-lettres in this country, leaving deep and lasting impressions in its wake. For a period of forty years thereafter the literary annual exerted an influence which altered the complexion both of literature and of art in the United States.

Its characteristics can be recognized easily. A representative literary annual possessed an elaborate binding, a vignette title page and presentation plate, a frontispiece and other engraved embellishments, a suggestion of gift or offering in the title, and a letterpress composed of prose and poetry by various authors, wholly or in part original. It was usually one of a projected annual series, each issue bearing the same title but differing in contents.

Naturally the annuals varied tremendously in quality and significance, those appearing during the first two decades having a much higher literary value than their successors. This was due largely to the fact that the pioneers in the field were so successful financially that other publishing houses rushed in to share in the success and profits. Some were none too ethical in 
their methods. Consequently, the earlier literary annuals, most of which were honest products, were largely superseded by fraudulent publications. Various devices were resorted to: change of title with similar letterpress, or with slight alterations, such as change of date, rearrangement of materials, new embellishments, the binding of loose issues of magazines with a false title page added, and the addition of the word "gift" or its synonyms to the title of an anthology, a compilation, or the selected works of one author in order to appeal to the holiday trade. It was actually possible to buy the same reading material for five, six, or seven successive years without duplicating titles or dates.

It is important to note that the gift books were intended as works of art as well as of literature. In general it may be said that the quality of the engravings was high, even though the prints were made primarily for the ordinary reader rather than the professional artist. Many of them were excellent, and were the principal cause of the publication's popularity and success. In fact, so important were the embellishments considered that frequently the stories and poems were written on order to illustrate the illustrations.

However, the primary concern here is with their literary aspect, and in connection with that it is interesting to reflect upon some of the famous authors who contributed to the annuals. Nathaniel Hawthorne contributed freely to Tbe Token, one of the best of the annuals, and his offerings included some of his best short stories. Edgar Allan Poe, in the midst of his heart-breaking struggle for existence, published $T$ be $P$ it and the Pendulum and other outstanding short stories in issues of $T$ be Gift. Longfellow, Bryant, Emerson, Lowell, Lanier, Simms are all represented by first publication of some of their creations.

Dr. Ralph Thompson has made the latest, and by far the best, study of this literary type in his book, American Literary Annuals E G Gift Books 1825-1865 (New York, 1936). Of the 855 items described, the Rutgers Library has copies of $30 \mathrm{I}$. Moreover, the Library possesses 46 additional items and variations of titles and imprints which were either listed but not located, or not listed in Thompson's checklist. Since the items in this catalog are unnumbered, it is necessary to refer to variants by page numbers. 


\section{A Supplementary Checklist of Literary Annuals Based Upon the Holdings of the Rutgers University Library}

I. Amaranth, for young people, containing articles principally from the pen of Mrs. Caroline M. Sawyer, editor of the "Rose of Sharon," author of the "Merchant's Widow," \&c. New York, Hallock \& Lyon, I $85 \mathrm{I}$.

Every contribution signed except one. Ten by Mrs. Sawyer and the remaining eighteen by ten other contributors. First title "The Fisherman" by Mrs. Sawyer.

2. The American Gift Book; a perpetual souvenir. New York, J. C. Derby, I 856.

Mentioned by Thompson, p. I6I, with no actual copy located. See plate facing this page.

3. Apples of Gold, in pictures of silver, edited by Edward B. Fellows. New York, Sheldon, Lamport \& Blakeman, 1855 . [c. I848].

Reissue of The Excelsior Annual . . . 1849, as listed by Thompson, p. I 8 . Imprint variation from the reissue located in the American Antiquarian Society.

4. The Book of Beauty. New York, Leavitt \& Allen, [c. I855].

Thompson, p. I07, mentions that this title is listed in Faxon, Literary Annuals and Gift Books (I9I2), and suggests that it might be a reissue of $T$ be American Book of Beauty. It is not. Contains six female portraits and stories and poems by L. H. Sigourney, Mary Howitt, T. K. Hervey and others. First title "Rita."

5. The Cabinet Annual; a Christmas and New Year's gift for MDCCCLV, elegantly illustrated. Philadelphia, E. H. Butler \& Co., I855.

All of the 23 engravings by Sartain, each illustrated by an appropriate poem or story. Most of the contributions signed. The first "The Two Fathers," by John Wilson.

6. The Child's Gem; a holiday gift. Edited by Mrs. S. Colman. Boston, T. H. Carter and Company, I844.

For children. A portion of the letterpress selected. The remainder, probably original, by "a blind child," Miss A. A. Gray, L.H.S., and others. First title "Sure the Rose is Like a Sigh."

7. The Christmas Box and New Year's gift for MDCCCXXXVII, a collection of amusement and instruction for the young. Philadelphia, Thomas T. Ash \& Henry F. Anners, [c. I836]. 


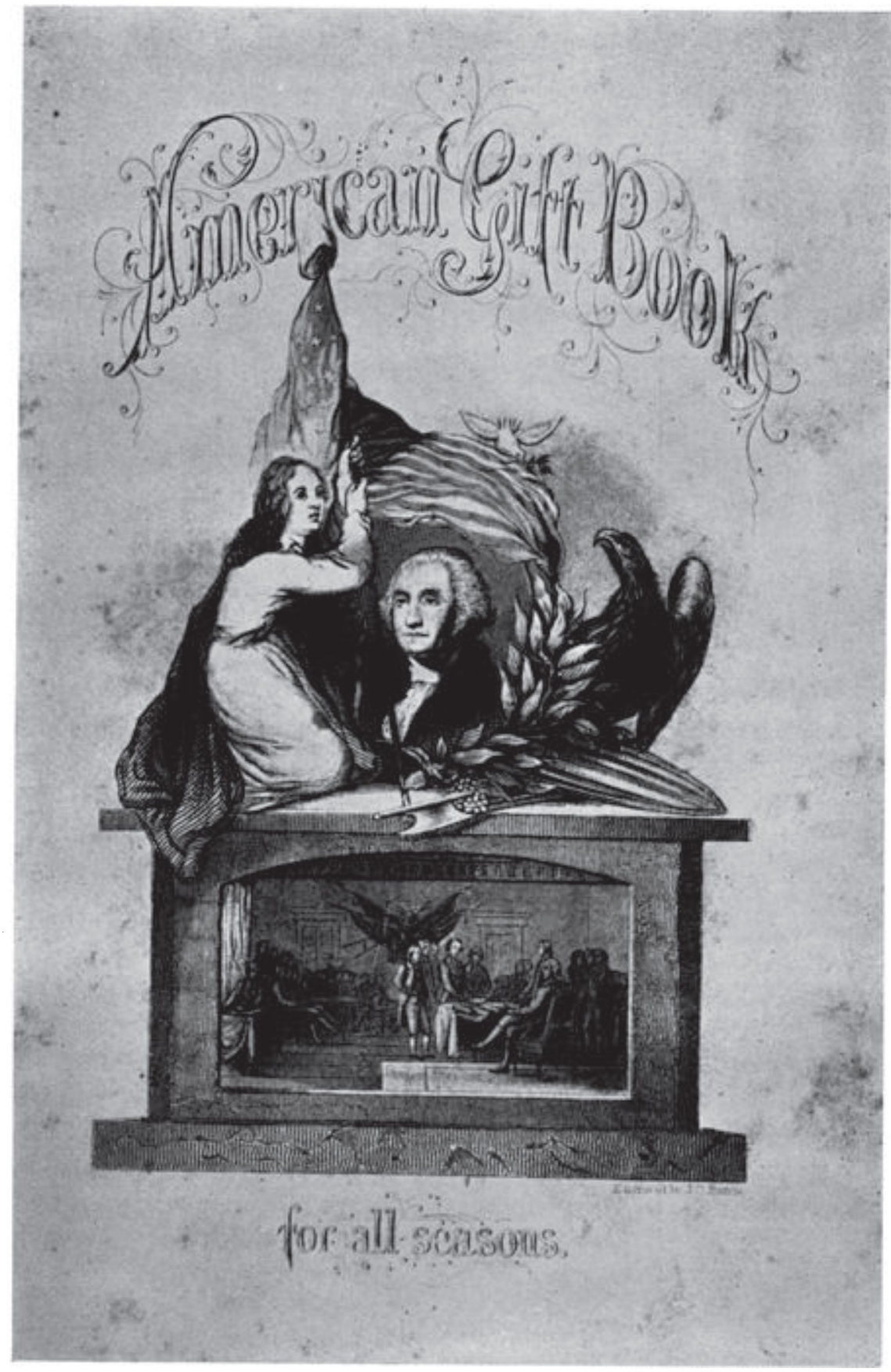


Letterpress partially signed, including such names as James Nack, N. Mitchell and Mary Howitt. Preface implies that the volume is in part selected. First title "Returning Home" by James Nack.

8. Christmas Roses and New Year's gift, a present for young people. Boston, G. W. Cottrell, [c. I848].

The preface states that with only "a slight change in title, and the lessening somewhat the number of engravings" this is an exact reprint of a volume published the previous year. Contributions usually unsigned, probably selected. First title "Proem" by the editor.

9. The Diadem, a present for all seasons. With ten engravings, after pictures by Inman, Leutye, etc. Philadelphia, Carey \& Hart, [c. 1 845 ]. Title and imprint dates crudely obliterated. Date 1846 on binding poorly concealed by gold leaf designs. Otherwise identical with The Diadem for 1846 , recorded by Thompson, p. I 18 .

IO. Floral Souvenir; a perennial gift with a complete floral dictionary. Chambersburg, Pa., Shryock, Reed \& Co., [c. I84I].

A reissue of The Lady's Book of Flowers . . . listed by Thompson, p. I33. Mention made of such a title, but no copy located.

I I. The Forget-Me-Not; a Christmas, New Year, and birthday gift. New York, Leavitt \& Allen [n.d.].

Letterpress largely unsigned, the few signatures including Mrs. Jameson, Jas. H. Dana, Bryant, and Tupper. Considering the publishers, probably entirely eclectic. Contents very similar to those found in Harvest Gleanings listed on p. 18.

I2. The Friendship's GifT or token of remembrance for I848. Dew drops of the nineteenth century. Edited by Seba Smith. New York, John Levison, [n.d.].

A reissue of Dew Drops of the Nineteentb Century ... a as listed by Thompson, p. II 7. This is a title variation not recorded there.

13. Friendship's Offering, a gift for all seasons; by Eugene Sinclair. Manchester, N. H., Fisk \& Stearns, 1858.

An unrecorded reissue of Gems for You, Thompson, p. 125. Binding title, "Offering of Friendship."

I4. The Gem of the Season; a souvenir for I853. New York, Leavitt and Allen, I 853 .

A title variation of the issue recorded by Thompson, p. 123. 
15. The Gem of the Season; stories and poems by eminent writers. New York, I 866.

False title page tipped in. Binding title "The Gift." The contents consist of a reduced and reorganized reissue of $T$ be Gift . . . for 1844 . One new poem, "Washington's Sword at the Capital," by Miss H. F. Gould, added.

I6. Gems for You; a gift for all seasons. By F. A. Moore. Manchester, N. H., William H. Fisk, I851.

A reissue with title and date variations of Gems for You . . . as recorded by Thompson, p. I25.

I7. Gift ror the Holidays. Philadelphia, American Sunday-School Union, [n.d.].

Contributions unsigned. However, the preface states that "The pictures in the present volume were procured on purpose for it, and the articles have been written or selected. . . ." For children.

I8. Good Girls' Annual; a Christmas and New Year's gift by Frances Broderip. New York, Allen Brothers, [n.d.].

For children. Letterpress consists of three long stories by Frances Broderip, G. E. Sargent, and Mrs. Russell Gray, followed by three comparatively short, unidentified stories. Perhaps Dr. Thompson would not consider this volume a true literary annual.

19. Harvest Gleanings, a holiday book. Edited by M. A. Dwight. New York, Gates, Stedman \& Company, I850.

First contribution "A True Story," by Mrs. Jameson. Preliminary statement implies that the letterpress may be entirely eclectic. cf. The Forget-Me-Not recorded on p. 17.

20. Holiday Tales, a juvenile forget-me-not, for all seasons. New York, W. B. Gilley, I 829 .

Most of the contributions signed. The first, "Garry Owen," by Miss Edgeworth. Probably most of the letterpress selected in view of the fact that most of the authors were English.

21. Homes of American Statesmen, with anecdotal, personal, and descriptive sketches, by various writers. New York, Alfred W. Upham, 1861. [c. 1854].

An unrecorded reprint of the item listed by Thompson, p. 129 .

22. The Juvenile Forget Me Not; a Christmas, New Year's and birthday present for I839. Philadelphia, Thomas T. Ash \& Henry F. Anners, [c. 1838]. 
Some of the contributions signed by James Nack, John Bird, and others. At least partially selected but probably containing some original material. Preface states that this was the first of a projected annual series. "My Sister Mary" the first title.

23. for 184I. Philadelphia, Henry F. Anners, [c. 1840].

Preface indicates that this volume was largely selected. Some contributions signed. The first, "The Alarm," by Miss C. H. Waterman. Engravings probably made to illustrate contributions.

24. The Lady's Annual Remembrancer, and literary forget-me-not for 1846. Philadelphia, Henry F. Anners, [n.d.].

A peculiar little volume. The first I 24 pages contain almanac entries and partially ruled pages for monetary and other memoranda. The last 43 pages contain stories and poems largely unsigned. "Louisa Banks," by Mrs. Hughs, is the first contribution.

25. The Laurel Wreath, or affection's keepsake. Original prose and poetry. Second edition, enlarged and improved. New York, T. P. Collins, I 844 .

A reprint, "with several omissions and additions," of the first issue, listed by Thompson, p. I33.

26. The Lily, a gift of friendship. New York, Cornish, Lamport \& Co., [n.d.].

An unrecorded reissue of $T$ the Lily, a coloured annual for $183 t$, as listed by Thompson, p. 136 .

27. The Little Gem, a Christmas, New Year's and birthday present. New York, H. Dayton, [n.d.].

Letterpress largely selected "with five or six original articles." The only contributor whose name is given is George P. Morris. Again, according to the preface, "the others, signed $\mathrm{K}$, have never before been published."

28. The Little Girt for I844. Edited by Mrs. S. Colman. Boston, T. H. Carter and Co., [c. 1843 ].

Letterpress partially selected. One poem, marked original, by L.H.S., probably Lydia Sigourney. Others initialed O.G.W., E.A.S., and P.A.C. For children.

29. Memory's Gift. New York, Geo. A. Leavitt, [n.d.].

A reissue of the Amarantb . . for 1849 with slight printing variations from the reissues noted by Thompson, p. I05.

30. The Moss Rose. New York, Leavitt and Allen, [n.d.]. 
Considering the publishers, probably entirely selected. Includes contributions by T. K. Hervey, the "author of Frankenstein," Miss Phoebe Carey, and others. First title "The Baron's Vow," by Miss Power.

31. The New-Year's Gift. Philadelphia, American Sunday-School Union, [n.d.].

For children. A poem, "The Late Spring," by Josiah Conder, is the only contribution signed. Articles probably written to suit the embellishments - the preface states that "the reading is of secondary consideration."

32. The Odd Volume, a collection of odds and ends, in prose and verse. By an odd fellow. Second series. New York, published for the booksellers, [n.d.].

Varies from the reissue, listed by Thompson, p. 144 , in that the binding date is 1841 .

33. The Peard; a gift of friendship, for I 853. Philadelphia, J. \& L. Gihon, [c. I $85 \mathrm{I}$ ].

Another variation of the Harvest Gleanings and Forget-Me-Not mentioned above. This volume contains four more stories than the undated Forget-Me-Not, the others agreeing exactly in number and in pagination, and many more than the earlier Harvest Gleanings.

34. The Remembrancer; or, fragments for leisure hours. Compiled by the Association for the Improvement of Juvenile Books. Philadelphia, T. Ellwood Chapman, i84I.

"A few of the pieces are now published for the first time, but most of them have been selected..."Authorship partially accredited.

35. The Rosette; a juvenile annual, for 1846 . Boston, Waite Peirce and Co., 1846 .

Letterpress probably original, at least in part. All of the contributions with two exceptions signed or initialed. The first, "The Poor Family," by the Rev. A. Stevens.

36. The Sabbath School Annual, edited by Mrs. M. H. Adams. Boston, James M. Usher, 1848 .

Thompson states, p. I 53: "Apparently no issue dated I 848 ."

37. The Sons of Temperance Offering, for all seasons. Edited by T. S. Arthur. New York, Cornish, Lamport \& Co., [n.d.].

An imprint variation of the reissues, listed by Thompson, p. I56. Contents remain the same. 
38. The Souvenir Gallery; an illustrated gift book for all seasons. Edited by Emily Percival. Boston, Phillips, Sampson \& Company, 185I.

Mentioned in Faxon, Literary Annuals and Gift Books, (IgI2). Thompson could not locate a copy, cf. p. I25.

39. The Temperance Offering. Edited by T. S. Arthur. New York, Leavitt \& Allen, [n.d.].

Differs from Thompson, p. I 56 , in that the word Offering is substituted in the title for Gift. His reference was taken from Faxon, no copy having been located.

40. The Token, or affection's gift, a Christmas and New Year's present. Edited by S. G. Goodrich. New York, A. \& C. B. Edwards, [n.d., binding I 840 ].

This is earlier than any of the reissues listed by Thompson, p. 159 .

4I. The Unique, or biography of many distinguished characters ... Third edition improved. Boston, Charles H. Peabody, 1830.

Thompson mentions no 3 rd edition, p. I6o. The preface to this edition states: "The Biographical Memoirs, which were before too prolix, have been abridged, and many anecdotes and original pieces inserted instead." A second edition is mentioned in the preface.

42. The Wreath, designed as a token for the young. Second edition. New York, Doolittle \& Vermilye, I836. [c. 1835].

A reissue of The Wreath . . I836, recorded by Thompson, p. I62.

43. The Young Lady's Offering, or gems of prose and poetry, by Mrs.

L. H. Sigourney; and others. Boston, Phillips, Sampson \& Co., I 849. [c. 1847 ].

Probably selected although some contributions might be original. Eight authors represented by 33 articles. The first, "The Father," by Mrs. Sigourney.

44 . Boston, Phillips, Sampson \& Co., I850 [c. 1847].

45. Boston, Crosby and Nichols, I862. [c. I847].

Reissues with no changes in the text. Slight rearrangement of the embellishments.

46. Youth's Keepsake, a Christmas and New Year's gift for young people. Boston, T. H. Carter, 1843 .

Imprint variations from the copies noted by Thompson, p. I63. 